\title{
Al-Tatawwur (Evolution): An Enhanced Timeline of Egyptian Surrealism
}

\section{Alexandra Dika Seggerman ${ }^{1}$}

The Egyptian-born and Sorbonne-trained writer Georges Henein formally introduced surrealism into Egypt in a public lecture at a Cairo conference in 1937. Shortly thereafter, a group of young artists gathered around Henein and dubbed themselves the "Art and Freedom Group." $\underline{2}$ Though they staged exhibitions in addition to their publications, the surrealists in Egypt have been less significant in the history of modern art for their formal innovations than for the way in which they changed the structure of making art. In the museums today, you might find a small sketch or painting by one of the founders of the surrealist movement, but you will not find their surrealist works in the prominent galleries. Whereas art production from the opening of the Cairo School of Fine Arts in 1908 through the 1930s was based on the community of artists in and around the school, the Egyptian surrealists introduced a way of art-making organized around self-identified art groups and articulated manifestos of artistic ideologies rather than solely around painted or sculpted objects. Their idea-based art and writings also allowed Egyptian artists of subsequent generations to engage with the local identity and heritage through more subtle means than their predecessors. Where earlier artists, such as Mahmoud Mukhtar and Mahmoud Said, employed clear visual references to both ancient Egypt and local culture, artists after the surrealists incorporated Egyptian identity into their art in a more theoretical way.

Though Henein became involved with the surrealist movement through his friendship with André Breton while residing in Paris, the Egyptian surrealists were well aware of the globalism of the movement beyond France. In an Arabic-language journal in Cairo, the painter Kamel el-Telmissany argued that surrealism was not French, but also Belgian, Mexican, Russian, German, and so on ("Hawla"1702). Notably, the Egyptian surrealists were allied from the beginning with the political artistic movement, the International Federation of Independent Revolutionary Art (F.I.A.R.I in French), founded by Breton and Trotsky at the house of Frida Kahlo and Diego Rivera in Mexico City. 
The following is an enhanced timeline of the development of surrealism in Egypt. It uses images and primary sources to give the reader a thorough picture of the development and impact of the movement, both in Egypt and in its points of contact with Europe and elsewhere. The timeline can be roughly divided into three sections. The first follows the career of Mahmoud Mukhtar, a sculptor who incorporated nationalist imagery of ancient Egyptian motifs and peasants into his modernist technique. The creation of his most famous sculpture, Egypt's Reawakening, took place during the discovery of the tomb of Tutankhamen and a heightened cultural engagement with the images of ancient Egypt. The second section presents information about the Egyptian surrealist movement, focusing on the founding of the Art and Freedom Goup in Cairo and its exhibitions and writings. The group broke with the nationalist rhetoric of the previous generation in favor of the universalism of surrealism and its political stance against totalitarianism. The final section of the timeline introduces the work of Abdel Hadi el-Gazzar who, as part of the Contemporary Art Group, adhered to a particular artistic ideology shared with like-minded artists. These artists who followed the surrealists adopted some of their techniques and attempted to access the "unconscious" of Egyptian society formally and theoretically while preserving the antitotalitarian purpose of their predecessors.

\section{Timeline}

May 1908: The École Égyptienne des Beaux-Arts, the first fine arts school in the Arab world, opens in Cairo under the auspices of twenty-six-yearold Prince Youssef Kamal, a wealthy member of the Egyptian royal family. Early students include painter Ragheb Ayad, sculptor Mahmoud Mukhtar, and painter and caricaturist Mohammed Hassan. Fields of study include Painting, Sculpture, Architecture, Design, and Calligraphy, and the school is staffed by mainly French and Italian instructors (École 6). Guillaume Laplagne, a classically-trained French sculptor, directs the school from 1908 through 1918, and the drawing and painting instructor is Paolo Forcella, an Italian Orientalist painter. Generally seen as part of a wider expansion of higher education in Egypt (today's Cairo University was founded the same year), the school is the first state-sponsored institution to teach fine arts. Notably, the Prince choses the French system, and French and Italian instructors, rather than the fine arts curriculum of the British occupiers. Unlike other colonized regions that adopted the educational system of the colonial powers, this Egyptian prince choses the opposing cultural force.

1910: First exhibition of student work from the École Égyptienne des Beaux-Arts held at the Cairo Automobile Club. 


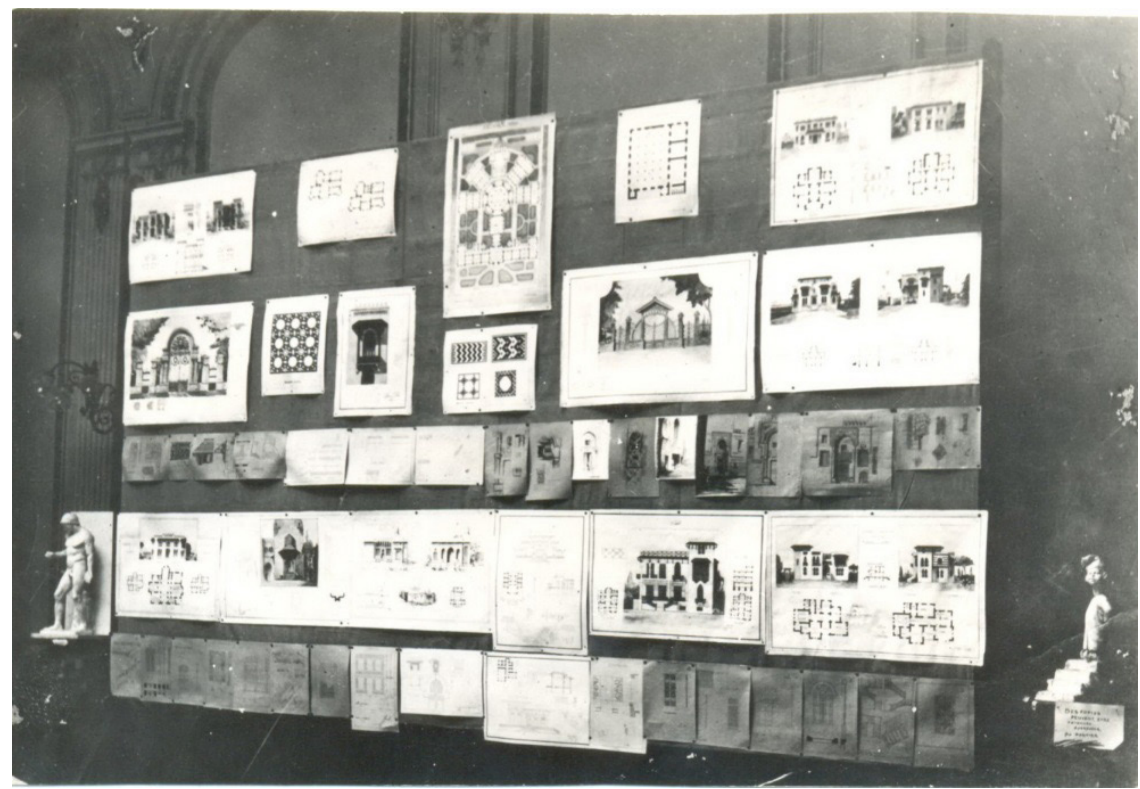

Figure 1: First exhibition of the École Égyptienne des Beaux-Arts, Cairo Automobile Club, 1910 (Collection Dr. Emad Abu Ghazi)

1911: Sculptor Mahmoud Mukhtar graduates from the school and is awarded a scholarship to attend the École des Beaux-Arts in Paris in 1912, again under the patronage of Prince Youssef Kamal. In Paris, his classmates immediately associate him with the ancient Egyptian sculptural heritage, parading him around the studio as "Ramses" as part of his hazing. . The $^{-}$ prince writes to Mukhtar:

You are Egyptian, and you must return to us Egyptian. You must work consciously in Paris, because we place all of our hopes in you. We wait impatiently the results of your hard work to prove that Egyptians do not lack in ideas and are not incapable of succeeding in the domain of Art, which is a manifestation of civilization (Abu Ghāzī and Boctor 46).

1913: Ramses Younan, surrealist painter, is born in the city of al-Minya, 150 miles south of Cairo.

1914: Georges Henein is born in Cairo, son of Sadiq Henein Pasha, a Coptic diplomat, and his Italian wife, Marie Zanelli. The elder Henein's appointments in Spain and Italy bring the young Henein to Europe, where he eventually completes his schooling at the Sorbonne.

1919: Popular revolution against the British Protectorate fills the streets of Cairo with protests, including groups of women led by the feminist nationalist, Huda Shaarawi. Protestors and politicians, headed by the 
nationalist Sa'ad Zaghlul, succeed in gaining a promise of independence for Egypt. Mukhtar, still in Paris and working briefly as the sculptural director at the Grévin Wax Museum, is inspired by these events and creates the first version of his most famous sculpture, Nahdat Misr (Egypt's Reawakening), a nationalist work blending modernist technique with pharaonic motifs. It receives honorable mention at the 1920 Salon of the Société des Artistes Français.

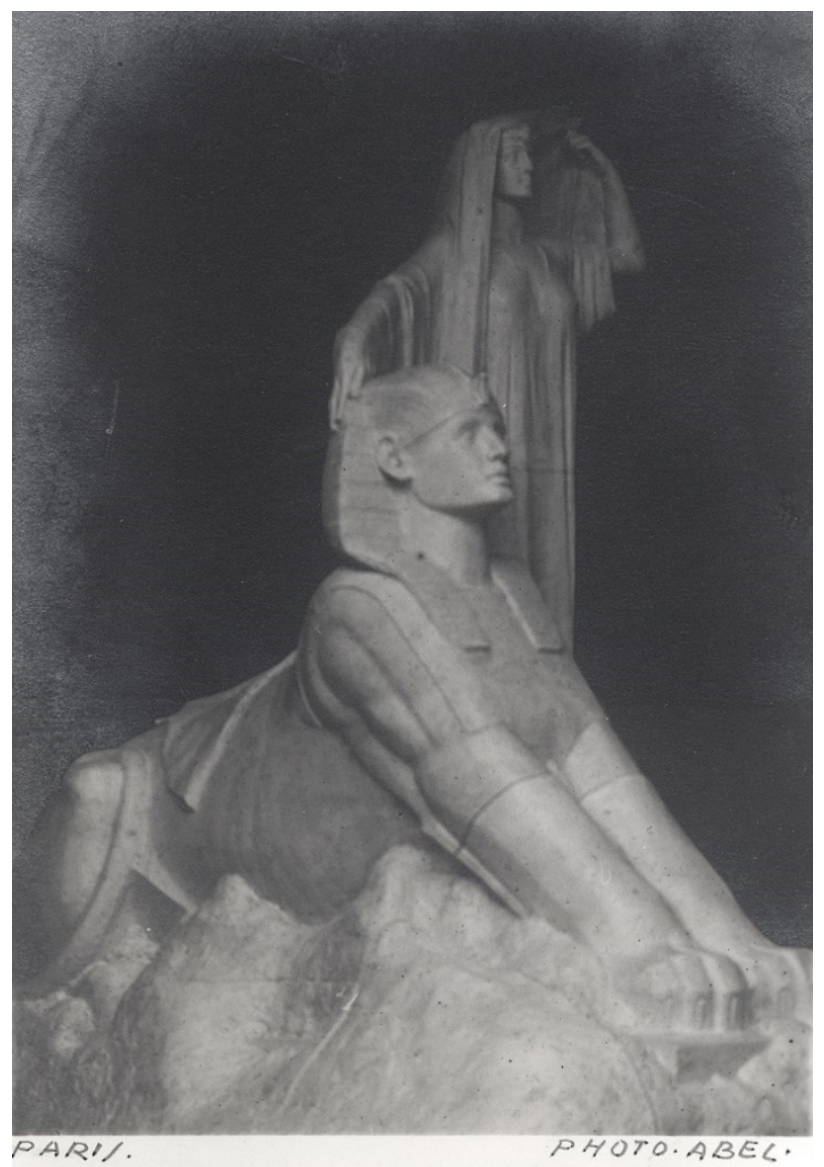

Figure 2: Mahmoud Mukhtar, first model of Nadhat Misr, 1920 (Collection Dr. Emad Abu Ghazi)

1920: A delegation of Egyptian students, in Paris to negotiate Egyptian independence, visits Mukhtar's studio, where he shows them his new sculpture before it is exhibited at the Salon. The delegation, captivated by the composition, decides to spearhead a campaign to commission a monumental version of Nahdat Misr for one of Cairo's public squares (Abū Ghāzī and Boctor 52). 
28 February 1922: Declaration of Egypt's independence issued by the United Kingdom, formally dissolving the protectorate created at the outset of the First World War in 1914. Though independent in name, the sovereignty of Egypt is restricted by the continued military and economic British presence, leading to continued tensions.

26 November 1922: The discovery of Pharaoh Tutankhamen's tomb by Howard Carter ignites Egyptomania worldwide. Carter remembered the discovery and his famous words about the tomb's "wonderful things:"

At first I could see nothing, the hot air escaping from the chamber causing the candle flame to flicker, but presently, as my eyes grew accustomed to the light, details of the room within emerged slowly from the mist, strange animals, statues, and gold - everywhere the glint of gold. For the moment - an eternity it seemed to the others standing by - I was struck dumb with amazement, and when Lord Carnarvon, unable to stand the suspense any longer, inquired anxiously, "Can you see anything?" it was all I could do to get out the words, "Yes, wonderful things." (Carter 141-42)

Even though pharaonism (al-fir'awniyya) in intellectual discourse previously had been an important aspect of Egyptian nationalism, the discovery of the intact tomb and especially the choreographed opening of the chambers in 1924 prompt an even stronger literary and artistic engagement with ancient Egyptian history (Gershoni and Jankowski 164). Writers, poets, artists, and thinkers incorporate pharaonic imagery into their work. Intellectual Muhammad Zaki Salih states in the newspaper Al-Siyasa alUsbu'iya that, "resurrected at the dawn of the Egyptian renaissance, he [Tut] has become the best expression of modern Egypt's determination to realize its goal of national existence" (cited in Colla 169). Alongside these changes, Mukhtar insists on creating his sculpture, Nahdat Misr, in pink granite from Aswan, like the ancient Egyptians, instead of bronze.

1925: Artist Abdel Hadi el-Gazzar is born in Alexandria, son of a scholar of Islamic law. At age eleven he moves to Cairo's traditional Sayida Zainab neighborhood when his father is appointed professor at al-Azhar University (Effat).

23 August 1927: Nationalist leader Sa'ad Zaghlul dies. Mukhtar develops two monumental sculptures of the leader for Cairo and Alexandria, incorporating pharaonic styles, mainly in the bases of the sculptures rather than in the portraits of Zaghlul.

20 May 1928: Mukhtar's monumental Nahdat Misr is unveiled in Bab elHadid Square directly facing the main train station. The event is produced with much fanfare and many prominent figures attend the event. 


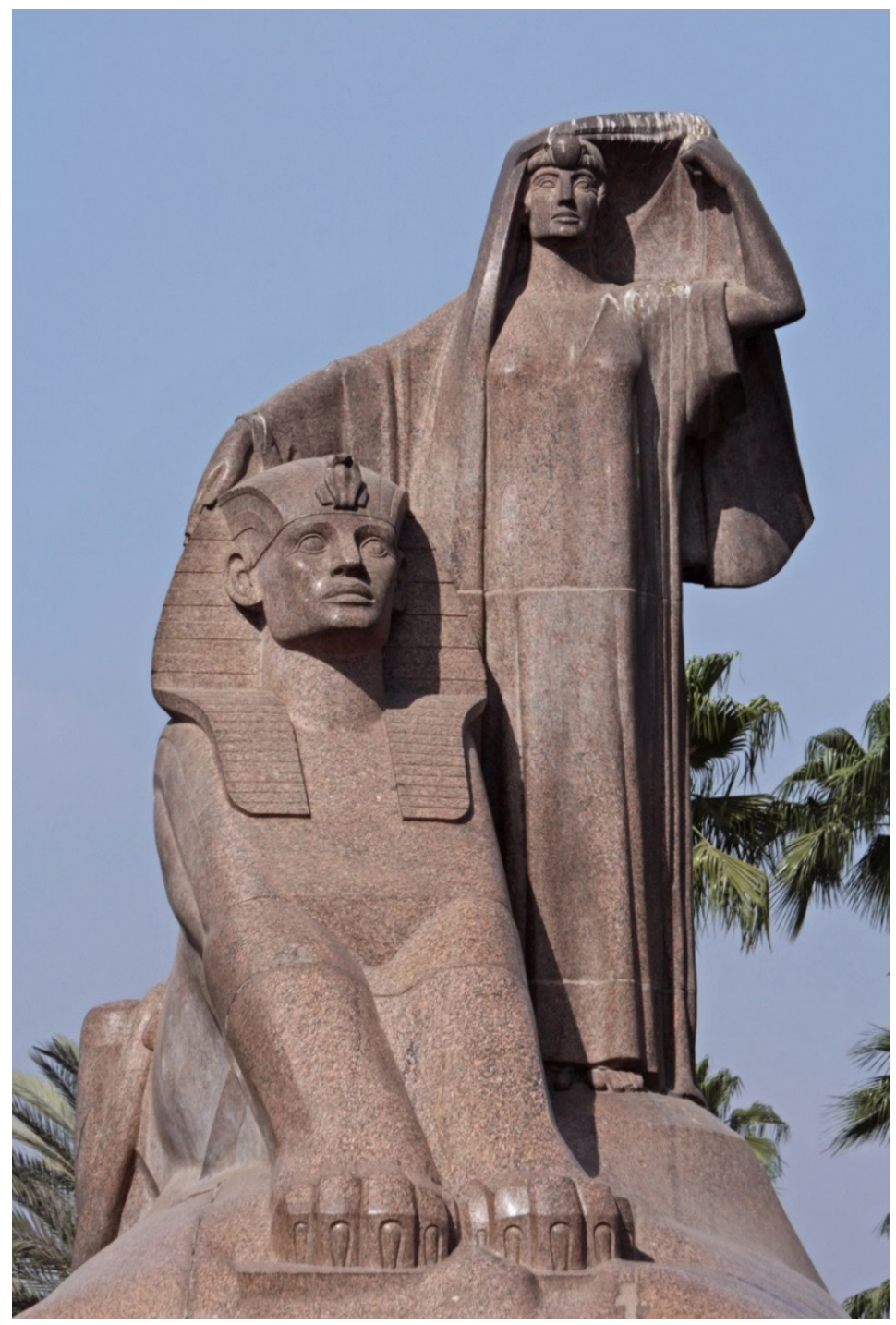

Figure 3: Mahmoud Mukhtar, Nadhat Misr, 1919-1928 (sculpture now located across from Cairo University bridge) (photograph by the author)

10 March 1930: Mukhtar has an exhibition at the Galerie Bernheim-Jeune in Paris, where he shows many small sculptures, influenced by pharaonic motifs as well as the image of the Egyptian peasant. The exhibition meets with positive reviews in the Egyptian and French press (Abū Ghāzī 162-85). The pieces represent the impact of ancient Egyptian artistic styles on modern 
art in Egypt, but they are also in line with the neoclassical work of Aristide Maillol and other artists of Europe's "Return to Order" movement of the 1920s and1930s.

1933: Ramses Younan graduates from the Cairo School of Fine Arts.

1934: Mukhtar dies in Cairo at the age of 43. Huda Shaarawi initiates a fund to support the creation of a museum for Mukhtar's works. During the same year, Georges Henein returns to Cairo from Paris. He writes a few articles for the francophone journal Un Effort and becomes involved with various literary pursuits in the city.

1936: King Fuad I, the regent since the end of World War I, dies and is succeeded by his 17-year-old son, Farouk. Farouk's opulence and later obesity are signs of the weakening monarchy, which is eventually toppled by the Free Officer's Revolution in 1952.

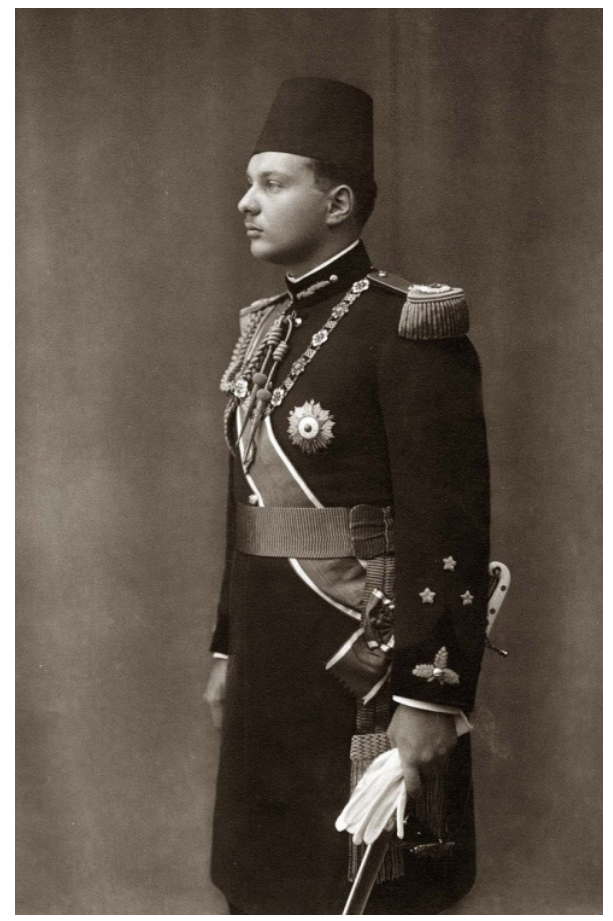

Figure 4: Photo of Young King Farouk in Military Uniform (Collection of Hassan Kamel)

In May, Henein returns to Paris, where he meets with André Breton following a brief written correspondence during his residency in Cairo that spring (Alexandrian 19).

1937: Henein publicly introduces surrealism in Egypt at a conference in Cairo and founds the Art and Freedom Group with artists Ramses Younan, Kamel el-Telmissany, and Angelo de Riz, journalist Emile Simon, and poet 
Edmond Jabés (Alexandrian 22). The group coalesces around a shared artistic ideology, and begins producing art and writing along the same lines. Henein, a Trotskyist, chooses the name "Art and Freedom" after the manifesto, "Pour un Art révolutionnaire indépendant," written by Breton with Trotsky in Mexico and signed by Diego Rivera and Breton (Alexandrian 22).

1938: Henein, only twenty-four, returns to Paris to finish his literature degree at the Sorbonne and also publishes a collection of poetry, Déraisons d'être (Unreason for Being) illustrated by Telmissany.

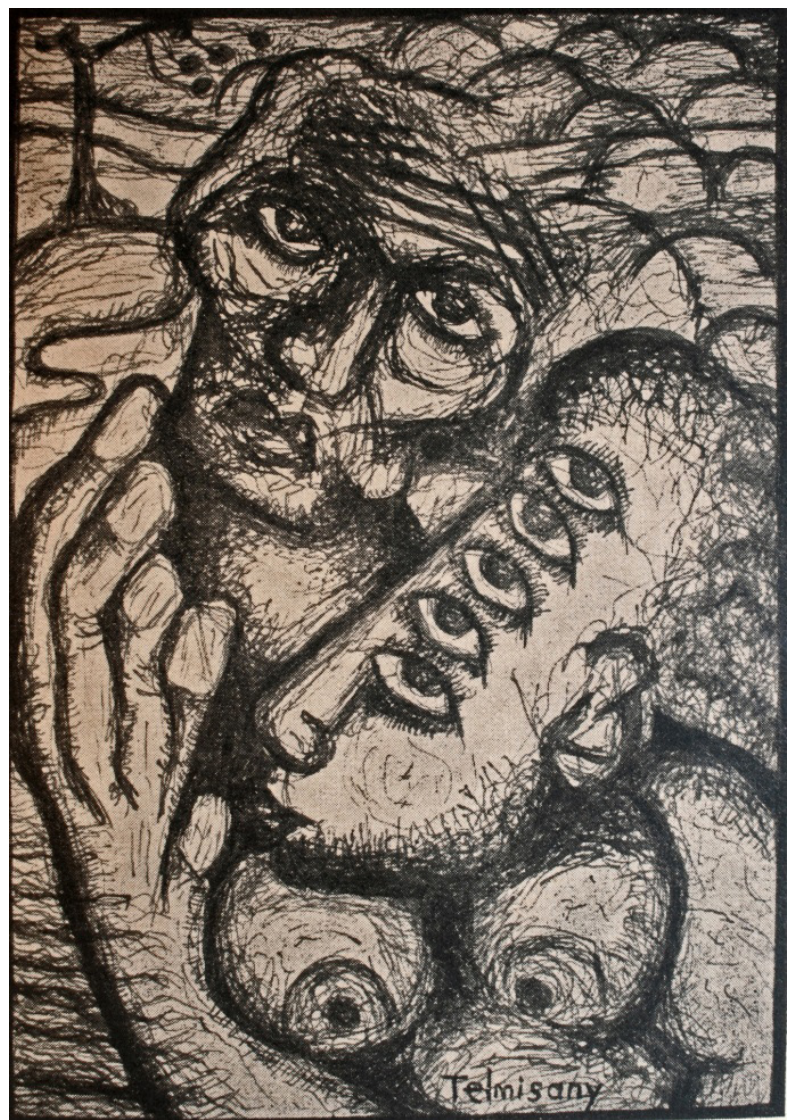

Figure 5: Kamel el-Telmissany, Illustration for Déraisons D'Être, 1938 
"Portrait of Kamel Telmisany" by Georges Henein

There you are, a beautiful black cloud, ready to pour down upon morality processions headed towards Judgment Day or whatever absurd daily bread.

I hear your words beating down on the stiffness of cities with the sound of a tree, playing at uprooting itself with its own hands.

It is really you, a frizzy fireball, who tears at the languid digestion of the leisure classes and who reverses with a casual gesture the landscape of those men bloated from their satisfaction with existence.

You know, like no one else, how to deflower the whores of the least anonymous thing they have, and raise their long-buried, enormous eyes to the surface of the day.

You know what to make of those trophies, snatched from the interior of despair in plain view of the grand path routed against the souls of honest men.

You love the linens withered once and for all - the beds to unmake love and the nocturnal terraces from where your pure blasphemes depart in pursuit of the heavens.

\section{Portrait de Kamel Telmisany \\ Georges Henein}

Te voilà beau nuage noir toujours prêt à fonder sure les processions morales en route vers le jugement dernier où je ne sais quel absurde pain quotidien.

J'entends s'abattre ta parole sur la dureté des villes avec un bruit d'arbre qui s'amuse à se déraciner de ses propres mains.

C'est bien toi bolide crépu qui arrache à la tiédeur de leur digestion tous les rentiers de l'aventure et qui renverse d'un geste négligent les paysage où se dilatent les hommes satisfaits d'exister.

$\mathrm{Tu}$ sais comme personne déflorer les putains dans ce qu'elles ont de moins anonyme et ramener à la surface du jour leurs yeux démesurés depuis longtemps ensevelis.

$\mathrm{Tu}$ sais faire de ces trophées cueillis à l'intérieur du désespoir des regards de grand chemin braqués contre les âmes des honnêtes gens.

Tu aimes les draps flétris une fois pour toutes, - les lits à défaire l'amour et les terrasses nocturnes $\mathrm{d}^{\prime}$ où tes purs blasphèmes partent à la poursuite du ciel. 
Your supreme feat will be this giant raid in whose arms will fraternize the gangsters and gendarmes of the whole world united against the whole world.

Beautiful black cloud, I see in you the chance encounter of the Apocalypse and the everyday. ${ }^{4}$
Ton suprême exploit sera cette rafle géante dans les bras de laquelle fraterniseront les bandits et les gendarmes du monde entier unis contre le monde entier.

Beau nuage noir je vois en toi la rencontre inespérée de l'apocalypse et du fait divers (2526)

In an un-dated letter, probably written shortly after the poem above, Telmissany writes to Henein, in English:

I took your poem and the French dictionary and a piece of two piaster from my young sister and went, without my sound healthy mentality which I left at my mother's sleeping room fortunately, and went to the "Azkabiya," where every girl is a sister and every sister is a wife. I spent a long time in translating your "portrait" and began to find something else of myself which was far away from me since a long time ago. Something where priests go to their prey with emerald green "costume de Bain" with red "tarboush" reading to their parishioners some lines of the Portrait of Dorian Grey or anything of Oscar Wilde... But, with true art, who cannot be but happy, even if he was in a city like Cairo. Art is nothing but a deep compensation to those few who were born poisoned as you knew dear boy. [sic] (reproduced in Gharib)

22 December 1938: On the eve of World War II, members of the Art and Freedom Group sign their manifesto, entitled "Long Live Degenerate Art," as a statement against the Nazi campaign to destroy "Entartete Kunst." It exhibits the group's political edge, expressly against totalitarian regimes, as well as the cosmopolitan composition of the group's members.

\section{Long Live Degenerate Art}

It is well known that modern society looks with aversion on any innovative creation in art and literature which threatens the cultural system on which that society is based, whether it be from the point of view of thought or of meaning.

Such feelings of repugnance are clearly visible in countries of a totalitarian nature, most particularly in Hitlerian Germany, where free art has met with extreme hostility and is now termed "Degenerate Art" by those ignoramuses. Artists from Cézanne to Picasso have been vilified, and the work that is the product of modern artistic genius with its sense of freedom, energy and humanity has been abused and trampled under foot. 
We believe that the fanatical racialist, religious and nationalistic path which certain individuals wish modern art to follow is simply contemptible and ridiculous.

We think that these reactionary myths will only serve to imprison thought. Art is, by its nature, a constant intellectual and emotional exchange in which humankind as a whole participates and which cannot therefore accept such artificial limitations.

In Vienna, which has now been abandoned to the barbarians, a painting by Renoir has been torn into pieces and books by Freud have been burnt in the public squares. Works by great German artists such as Max Ernst, Paul Klee, Karl Hoffer, Oskar Kokoschka, George Grosz and Wassily Kandinsky have been confiscated and replaced by worthless National Socialist art.

Similarly in Rome, a committee has recently been formed "for the purification of literature"! It has taken up its duties and has decided to withdraw everything that is "anti-Italian, anti-racist, immoral and depressing."

Intellectuals, artists and writers: Let us stand together and accept the challenge! We must align ourselves alongside this "Degenerate Art," for in such art reposes the hopes of the future. Let us work to support it so that it will prevail against the new Middle Ages which they are trying to resurrect within the heart of Europe.

This statement has been signed by artists, writers, journalists and lawyers. Their names are as follows: Ibrahim Wassily; Ahmed Fahmy; Edouard Pollack; Edouard Levy; Armand Antebi; Albert Isra'il; Albert Cosseri, Kamel el-Telmisany; Alexandra Mitchkovski; Emil Simon; Angelo Paulo; Angelo De Riz; Anwar Kamel; Annette Fadida; A. Politis; L. Galanti; Germain Isra'il; Georges Henein; Hassan Subhi; A. Rafu; Zakaria al-Azouni (from the Union of Lawyers); Sami Riyadh; Sami Hanouka; Scalet; Abdul Khaliq al-Azouni; Fatima Na'amat Rashed; Fouad Kamel; Kemal Wiliam; Luarent Salinas; Marcelle Biagini; Marcel Nada; Malanos; Muhammed Saif-el-Doen; Muhammed Nur; Nadif Selair; Hassia; Henry Domani.

Cairo, December 22, 1938 (trans. in Rosemont and Kelley 148)

March 1939: First bulletin of Art and Freedom group issued.

August 28, 1939: Telmissany publishes a response to an article in $\mathrm{Al}$ Risalah, on surrealism, in which he states:

Surrealism is not a "specifically French movement" as the professor said, rather it is a movement that is primarily defined by the globalism of its thinking and its actions... It is not only between the French leaders, the painter Giorgio De Chirico is Italian-Greek, Salvador Dali is Spanish just as Picasso, Paul Klee and Max Ernst are from Germany, Ben Rose is English as is Henry Moore, Paul Delvaux likewise is Belgian, and Chagall is of Russian origin, among others... 
Have you heard stories or poems from local, popular literature?.... All of these, Sir, are all surrealist.

Have you seen the Egyptian Museum?... Much of pharaonic art is surrealist.

Have you seen the Coptic Museum? Much of Coptic art is surrealist (el-Telmissany, “Hawla” 1702).

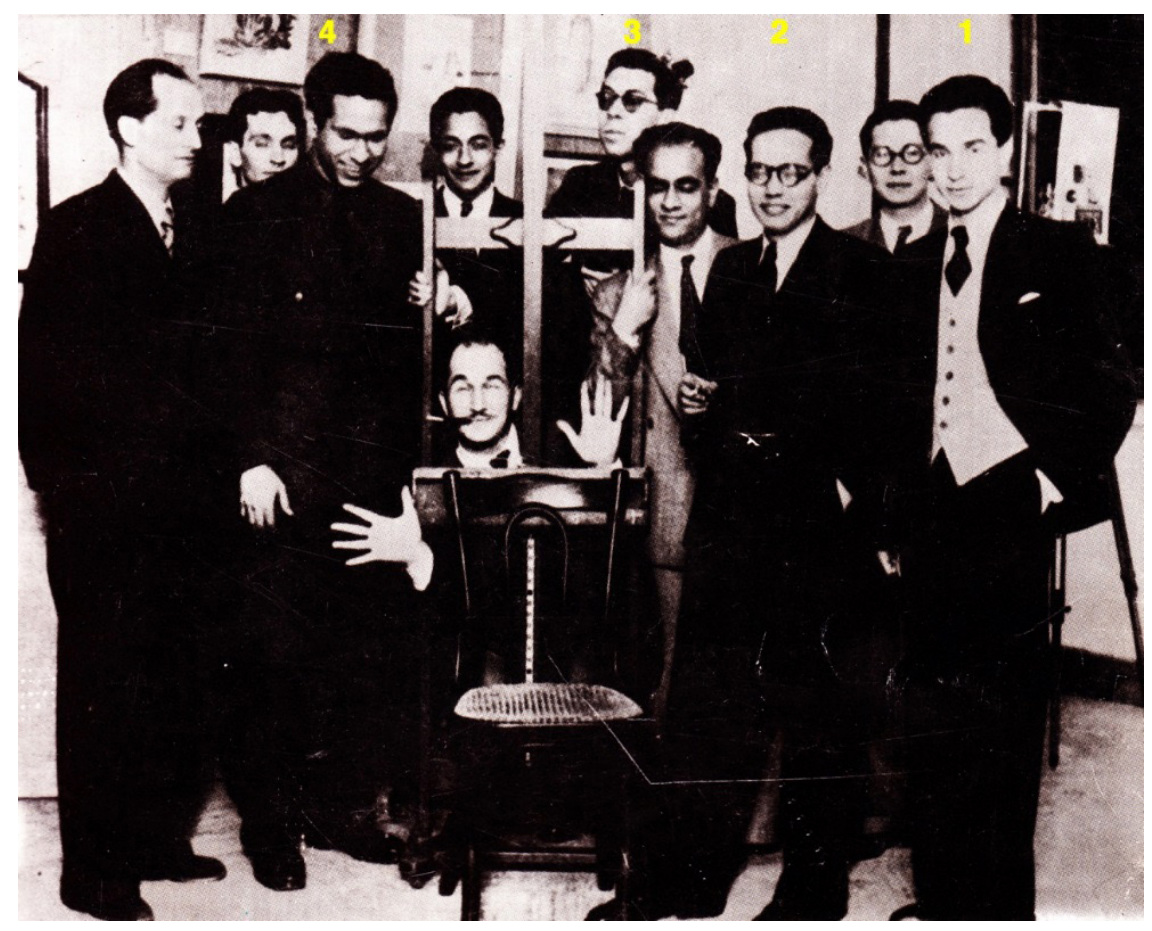

Figure 6: Photo of the Surrealist Group: 1. Foud Kamel 2. Ramses Younan 3. Georges Henein 4. Kamel el-Telmissany (repro. in Gharib)

December 1939: Don Quichotte magazine begins, under direction of Henein, published with the motto: "We struggle against: indifference, anachronism, facility, the use that people don't make of freedom, all falsifications, and all euphemisms" (qtd. in Rosemont and Kelley 137) 
Works from the Museum of Modern Egyptian Art Cairo, Egypt

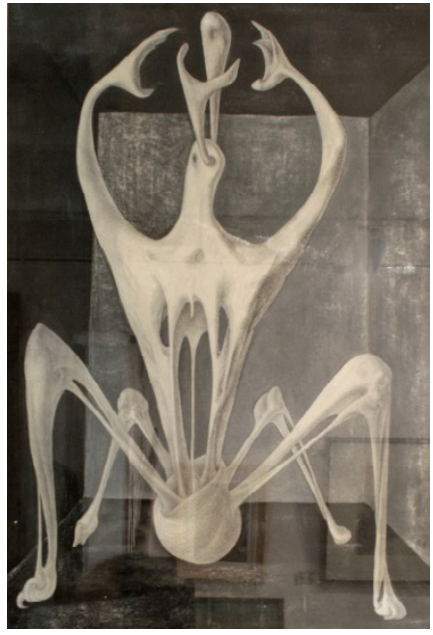

Figure 7: Ramses Younan, Figure, c. 1939

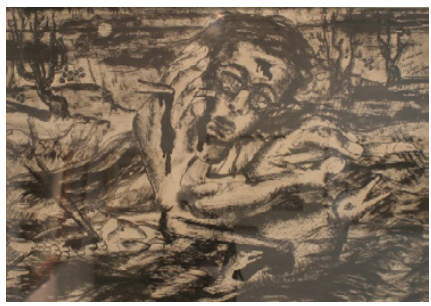

Figure 9: Kamel el-Telmissany, Tragic Poem

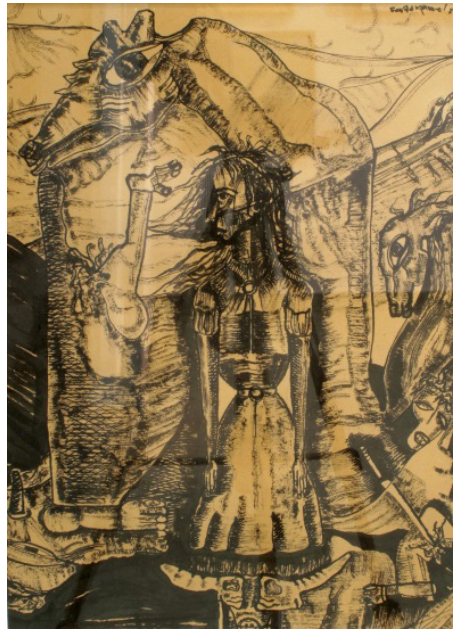

Figure 8: Fouad Kamel, Moves of Lust, 1939

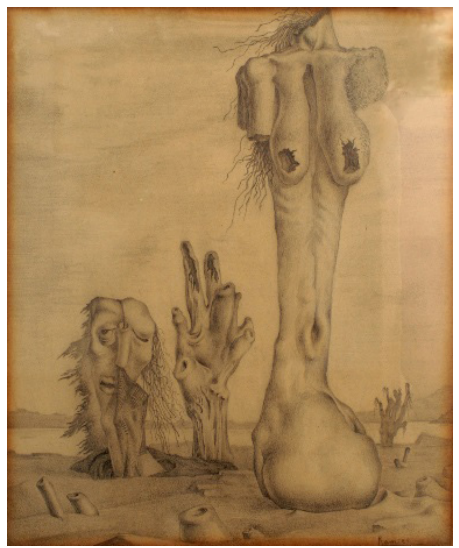

Figure 10: Ramses Younan, Sand, for Georges Henein, 1939

January 1940: The first issue of the group's Arabic-language magazine, Al-Tatawwur (Evolution), is published. Self-dubbed "The first avant-garde literary and artistic review in the Arabic language" (Alexandrian 30). 


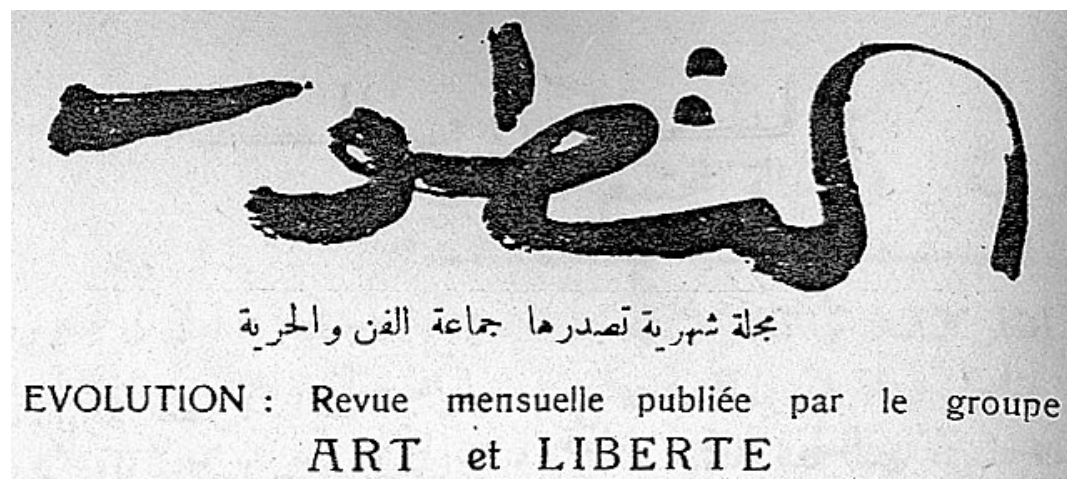

Figure 11: Masthead of Al-Tatawwur Magazine, 1940

8 February 1940: First exhibition of the Art and Freedom Group, called "From Mahmoud Said to Fouad Kamel," is held in Cairo. Interestingly, the group includes the work of the older painter, Mahmoud Said, who does not consider himself a surrealist and has been producing stylized figural oil paintings since the early twenties. Perhaps, as with Picasso and de Chirico, the surrealists consider him a "found" surrealist.

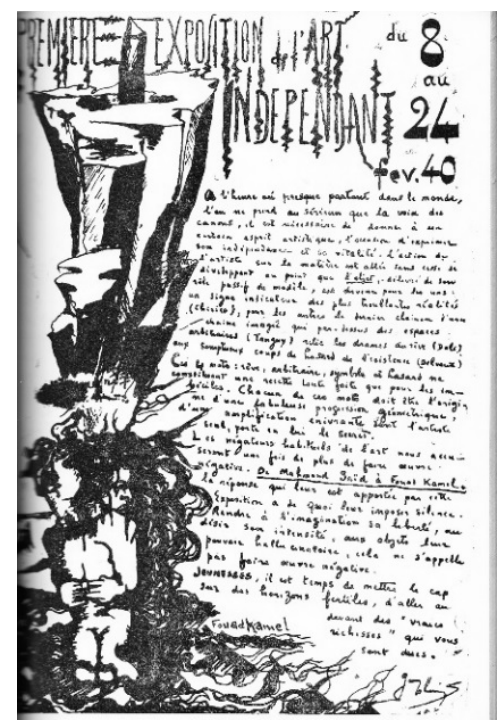

Figure 12: Catalog cover for the first exhibit of "Free Art" Text by Henein, drawing by Fuad Kamel (repro. in Gharib)

In the same month, the second issue of the Art and Freedom Group's journal, Al-Tatawwur, is published. Tawfiq Hana' Allah sums up the group's goals: "Our primary task is to establish a school where we can teach people 
how and why they should be discontented, discontented with the chains that bind them and the society whose values are set in stone" (translated in LaCoss 29). Kamel el-Telmissany also publishes an article called "Humanism and Modern Art":

The humanist feeling and what it means in our current era of crisis is one of the problems that is addressed in modern art, and, I believe, is the most important and deserving for investigation. Humanism is the primary characteristic that defines Free Art, in which you elevate areas hidden by the narrowness of partisanship, which limits art and undoubtedly eliminates its most important characteristics, in order to prioritize the expression of the exact meaning of life and its painful problems. Art will not be a tool for pleasure of people to bring joy to their idle minds. Cheerfulness is far from humanism and life that crashes and keeps crashing every day. This bold call that fills the rubble was yelled by voices, some of them from the new Free Art, and called for by humanist literature before. Some of the voices who called for it were the Russians Korsakov and Dostoevsky (45).

March 1940: In response to and in conjunction with the exhibit, many of the members of the group publish pieces in local publications in both French and Arabic. In the journal Don Quichotte, Telmissany writes:

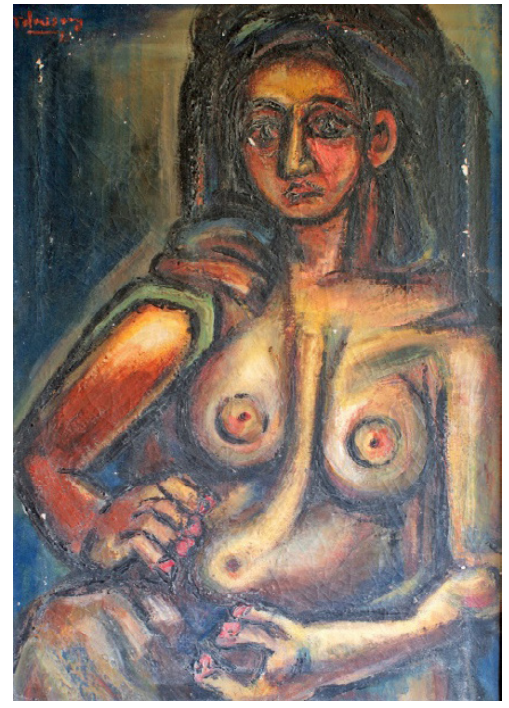

Figure 13: Kamel el-Telmissany, Nude, 1941

(Collection of Fatenn Moustafa)
Art does not belong to a territory. Chirico is not more Italian than Delvaux is Belgian than Diego Rivera is Mexican than Tanguy is French than Max Ernst is German than Telmissany is Egyptian. All these men participate in the same fraternal struggle against the logic of the bell tower and of the minaret, which do not know how to raise even a pathetic barrier (qtd. in Alexandrian 29).

10-25 March 1941: Second exhibit of the Art and Freedom Group is held. 


\section{Art \& Liberté}
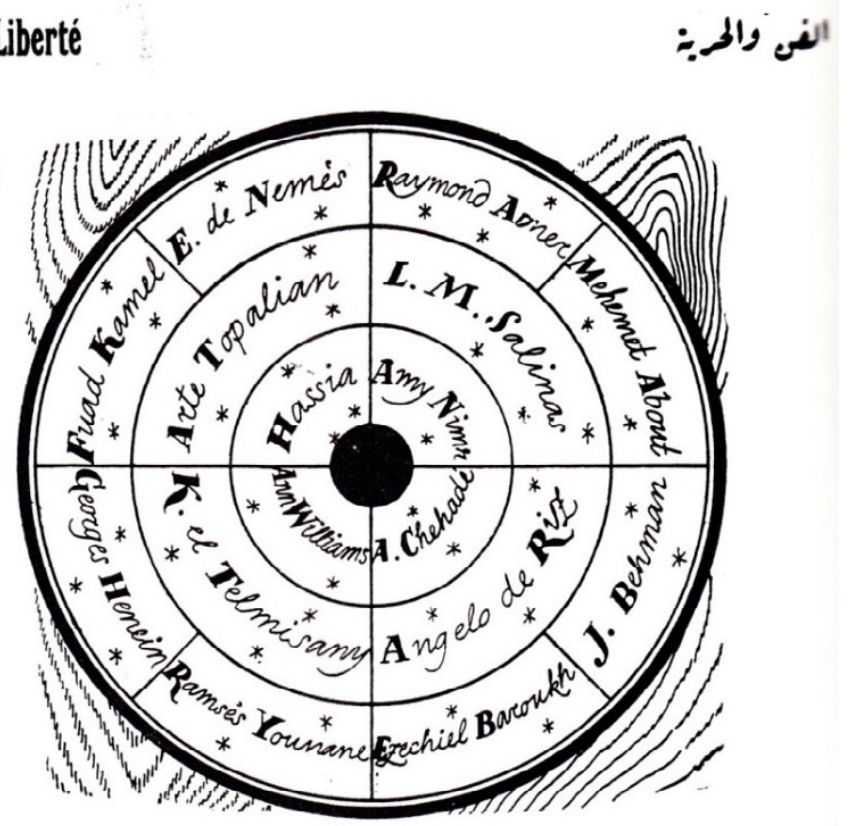

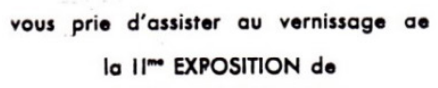

L'ART IMDEPENDANT

qui aura lieu le Lundi 10 Mars à 18 h., au 26 Rue Madabegh (Bloc Nord, entresol), dans les locoux de I'IMMOBILIA.

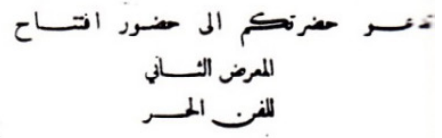

ن الساعة السلدسة من يوم الاثنين

.

شلرع المدابغ حץ ( القسم الثلالى)

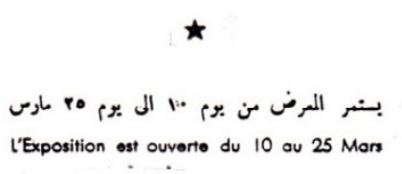

unminear un moceds

Figure 14: Catalog cover for the second exhibit of "Free Art" Text by Henein, drawing by Fuad Kamel (repro. in Gharib)

1945: Ikbal El Alailly, an active member of the surrealist group and Henein's partner and future wife, publishes the anthology Vertu de l'Allemagne (The Virtue of Germany), in her words, in order "to render homage, today, to the generous German contribution to modern thought and to the orientation of all contemporary poetic activity." Honoring German culture was clearly a unique stance at the close of World War II. She writes: 
One can say what one likes of the slip-streams and fluctuating episodes of this exhausting struggle, to which the mouth of the poet returns again and again, and the taste of death and the hatred of possible servitudes in the poet's interaction with the everyday world. It remains to the credit of German romanticism that it traced, for the poetic and artistic inspiration of the nineteenth and the twentieth centuries, our major ways of seeing. In his immoderate ambition to transfigure all things or to perish the romantic poet - albino voyager who, only yesterday, plunged into the night to become its fantastic chronicler - now learns, and not without delight, to taste light itself, like a long-forbidden fruit. Already it is the poet's own light, and its various reflections illuminate and touch all that is madly desirable in this world, thereby inciting people to liberate themselves from the false night that ignorance and tyranny have imposed on them in recent years. False night of war, false night of frenzied provocations that end up ruining all intelligence and all culture in a volkish and folkloric chauvinism. False night of slavery and flayed susceptibilities, oh, the time lost in "national hostilities!" False night for real and too numerous brigands at all points of the horizon. False night the ultimate negation of poetry, of the right of poetry, of the poetic sensibility that humankind has evolved. False night that must be swept away once for all, so that we shall awaken one morning to find the very air we breathe flowering with freedom, this other ocean (trans. in P. Rosemont 194-95).

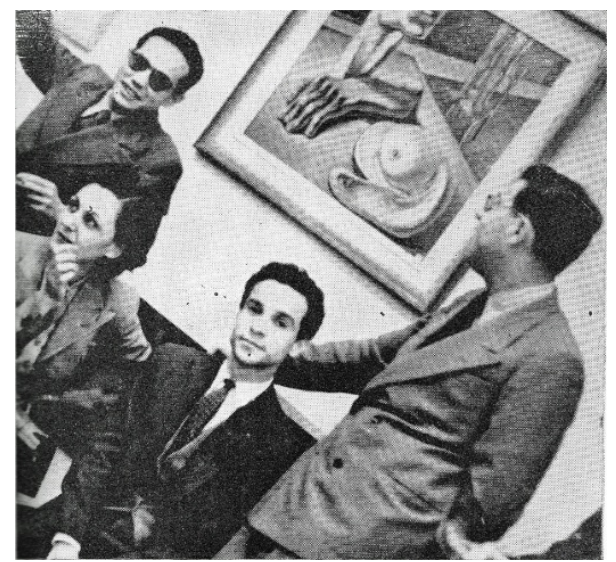

Figure 15: From right to left: Georges Henein, Fuad Kamel, Ikbal El Alailly, and Ramses Younan (repro. in Gharib)

In the same year, Telmissany directs the realist film, Al-Souq al-Souda (The Black Market), which leads to a career in filmmaking. Influenced by his growing interest in Marxism, Telmissany decides to leave painting for film in order to reach more of the populace (May Telmissany). Arguably one of the first realist films produced in Egypt, Telmissany depicts the lower-class life 
in the city in a critique of capitalism and its impact on the people. In concert with the purpose of the film, he hired an unknown man from the street to act in the main role and depicted a man with a disability, a stark contrast to the glossy films of the 1930s depicting an upper class lifestyle and idealized peasants.

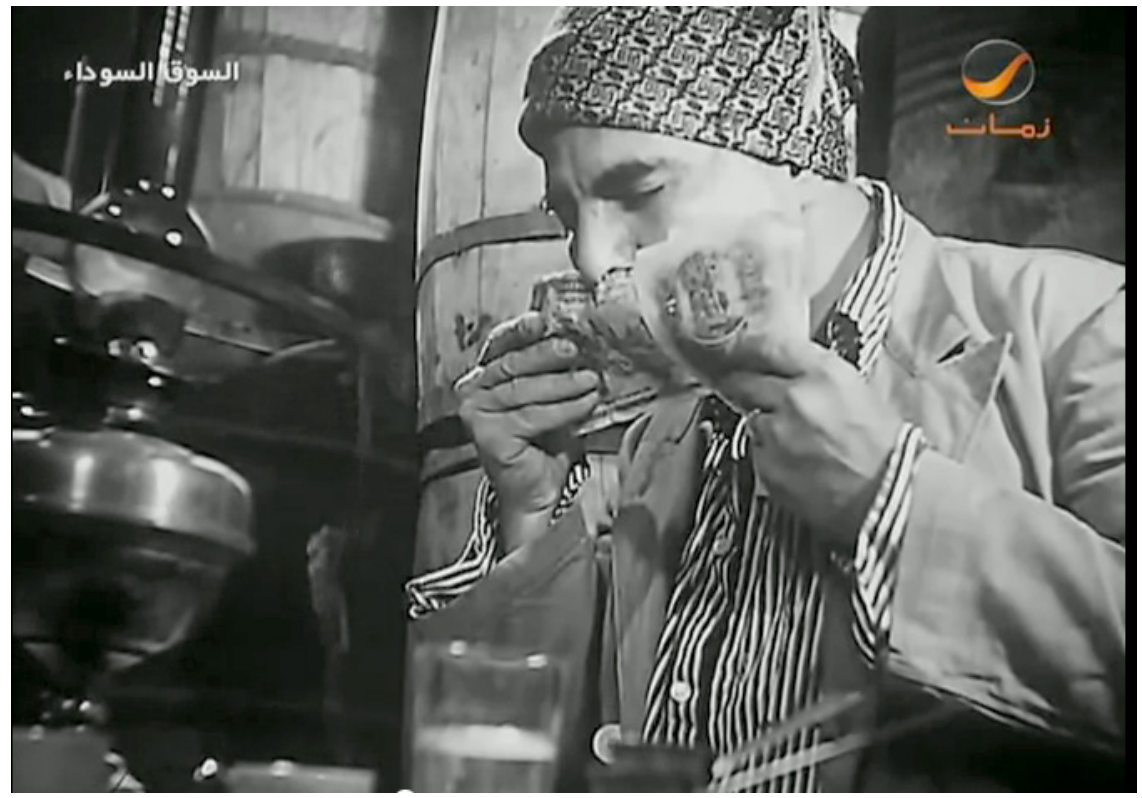

Figure 16: Still from Al-Soūq al-Soūda '[The Black Market], 1940-5 Directed by Kamel el-Telmissany

1946: Hussein Yusuf Amin, an artist recently returned from Italy and Brazil, forms the Contemporary Art Group with young artists, some of whom he taught drawing at Helmiya Secondary School. These are Hamed Nada, Abdel Hadi el-Gazzar, Samir Rafei, Maher Raef, and Kamel Youssef. Amin drew artistic ideas from his encounters with artists in Europe and Latin America, and was close with Salvador Dalí in Florence. The Contemporary Art Group gathers every week at Amin's house near the Giza pyramids to discuss art and artists (Amin). Though not a professor at the Fine Arts College, Amin has an influential impact on these young art students, and their artwork and outlook is clearly influenced by the surrealists.

In the same year, Younan is arrested for his political activities and flees to France after he is released. Younan remains in France until the Suez Canal Crisis in 1956 forces him back to Egypt (Khalil, The Arab Avant-garde 99).

1947: First exhibit of the Contemporary Arts Group is held at the Bab elLouq Lycée. 
1948: Gazzar is jailed overnight for his painting Popular Chorus, which depicts a line of city dwellers with empty bowls before them. Though a gifted draftsman, Gazzar chooses a primitivist style to depict the superstitions and traditional practices of residents of Cairo's lower-class districts, such as his own childhood neighborhood of Sayida Zainab. Instead of employing clear references to Egyptian history and culture as in the work of Mukhtar, Gazzar explores the undercurrents of Cairo's society in both style and content, in order to reach a more complex expression of Egyptian identity. Though not a self-defined surrealist artist, Gazzar and the members of the Contemporary Art Group are affected by the way in which surrealists encourage art that breaks from heroic subject matter and criticizes political oppression.

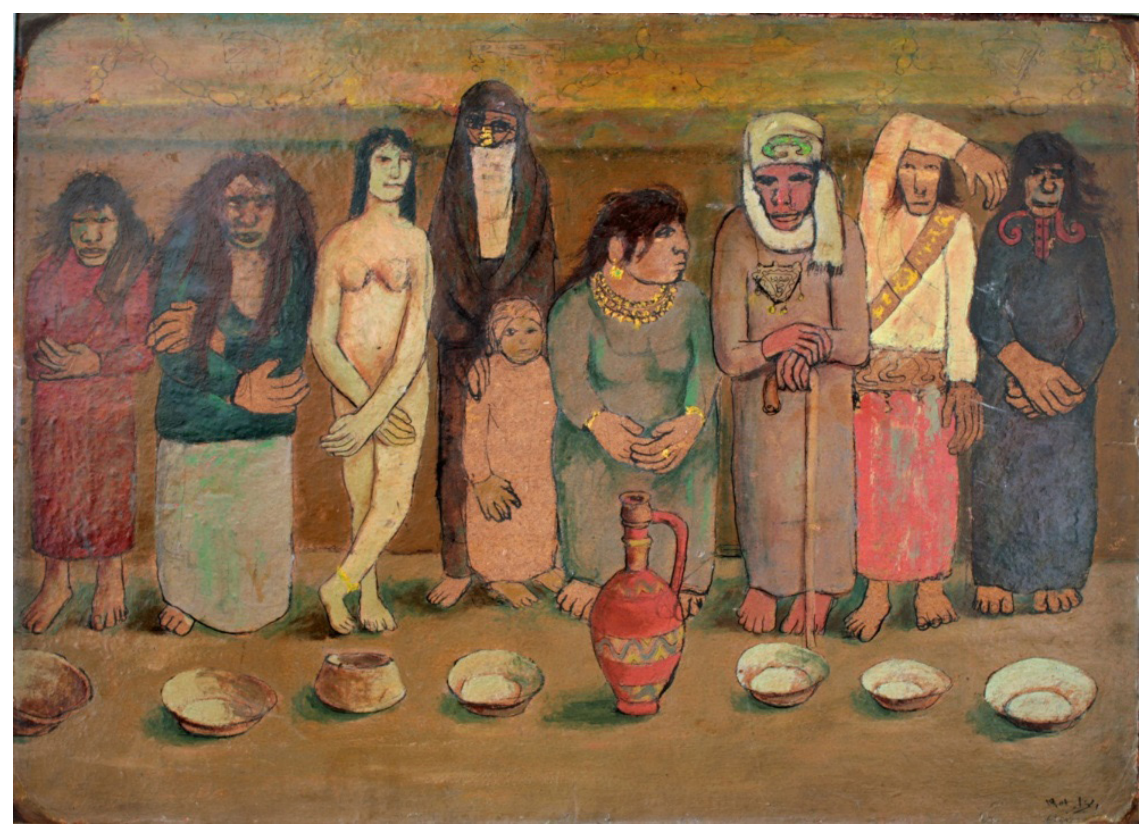

Figure 17: Abdel Hadi el-Gazzar, Popular Chorus, 1949

(Collection Naguib Sawiris)

In the same year, Henein and Younan publish a joint piece, "Notes on a Hysterical Asceticism," in which Younan states: "I am inclined to MAKE LOVE WITH APPARITIONS . . . that takes place on a precarious plane, suspended somewhere in the void. No sky, no earth, no dictionary..." (trans. in Khalil, "The Myth of the False" 104)

1 May 1948: Second exhibition of the Contemporary Art Group at the Service de Jeunesse in downtown Cairo. 


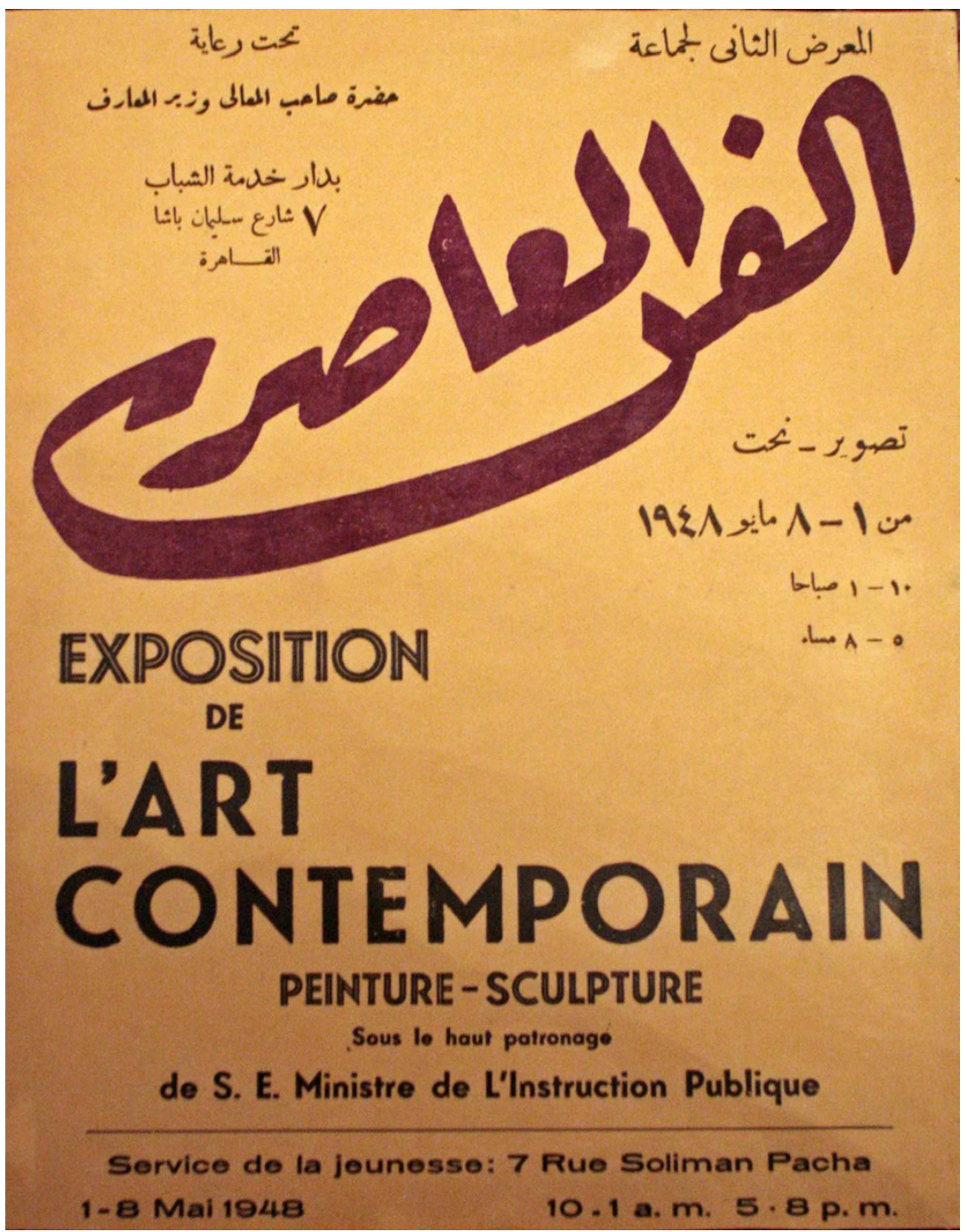

Figure 18: Poster for Exhibition of the Contemporary Art Group, 1948 (Collection Leila Effat)

26 July 1948: After twelve years of continued correspondence with Breton and a formal participation in his surrealist group, Henein officially breaks with the group in a letter to Breton:

I write without humor and without spite. The decision to leave a group which is worthy and in which we have shared twelve years of joint activities, is not undertaken with a merry heart. I would like to say right away that I do not find myself in disagreement with the 
basic positions of surrealism, the figures who have paved the way... for me, are a constant help, and ultimately its paths of research remain, I think, the most uplifting (cited in Alexandrian 53).

The reasons for Henein's break with Breton are many, but the impact of the creation of Israel and the resulting Arab-Israeli War seems to have been significant. As explained by Henein's biographer, Sarane Alexandrian, a painter of the group "[claimed] that it was contradictory for surrealism, having always fought the state, might now help form a new one" (56). However, Alexandrian describes Henein's malaise with the group as starting much earlier, with the perceived discrimination in an exhibition of 1947 and then the secret publication of a new serial - Néon - in January 1948. In the letter to Breton, Henein cites both of these productions as "better than nothing" and expresses his disappointment with their quality (53-56). Henein's "inquietude" with the group thus stems from both political and artistic disillusionment with the activities in the postwar environment.

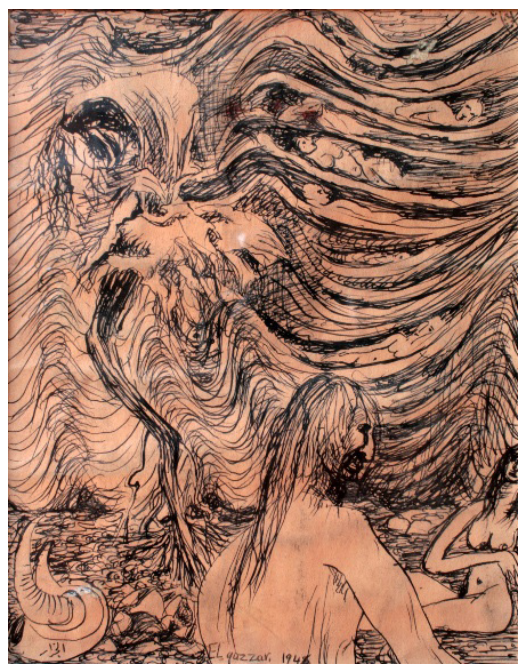

Figure 19: Abdel Hadi el-Gazzar, From the Primal Stage, 1948 (Collection Leila Effat) 
1950: Gazzar graduates from the Cairo School of Fine Arts. 1951:

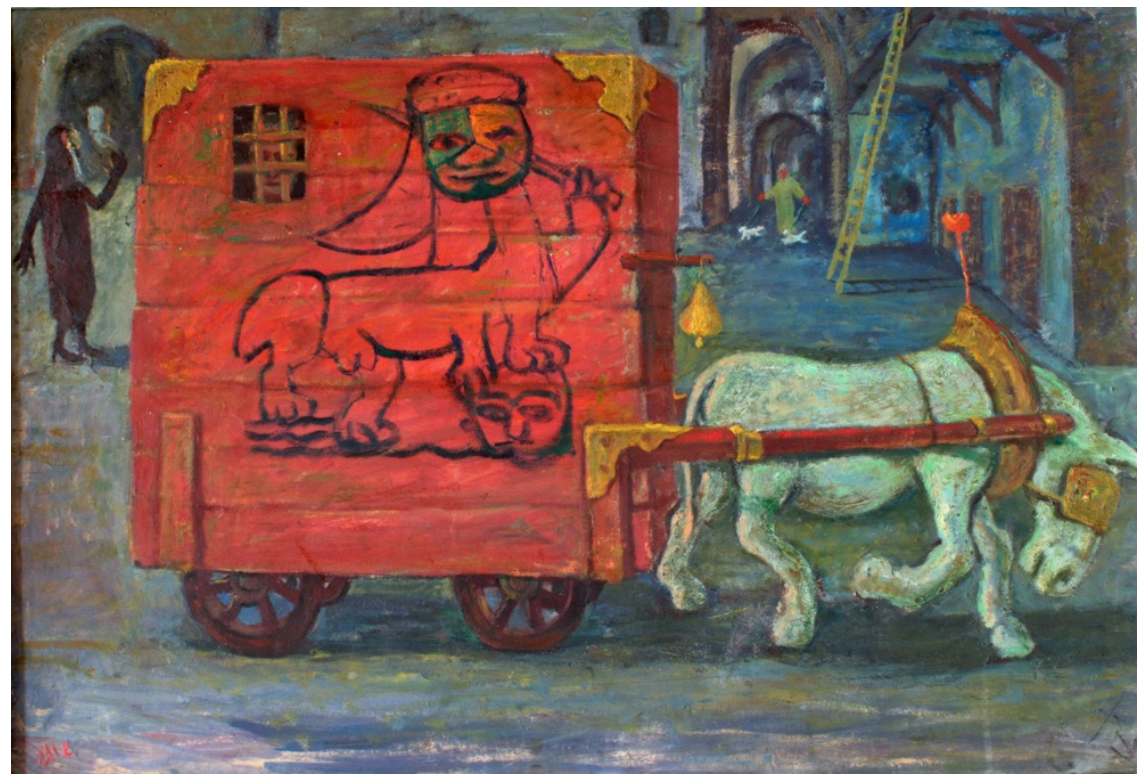

Figure 20: Abdel Hadi el-Gazzar, Circus Cart, 1951

(Museum of Modern Egyptian Art)

1952: Free Officer's Revolution in Cairo overthrows the monarchy and forces King Farouk into exile. The young and charismatic Gamal Abdel Nasser becomes president of the new republic in 1954 and pushes the country toward socialism. Officially part of the non-aligned movement, these new policies have a positive impact on artists, funding international study as well as artists' grants in Egypt. The state becomes the largest patron of the arts, which has a profound impact on the avant-garde political art of the surrealist group. Though some artists, like Gazzar, incorporate surrealist techniques to promote the new state, others, like Telmissany's protégé Inji Eflatoun, use art to continue to advocate for leftist causes. Eflatoun, an ardent communist and feminist in both painting and writing, is eventually jailed for her activities in the late 1950s (Aflātūun).

1954: Gazzar is awarded a scholarship to study in Italy. His first visit lasts six months, but he returns to Italy in 1956 and remains there until 1961, receiving a diploma from the Central Institute for Restoration in Rome. His interaction with science at the institute prompts his art to become more focused on technology and, in particular, space travel.

1956: After ten years living in France, Younan returns to Egypt after refusing to defend France's position in the Suez Crisis. 
1962: After returning from Italy, Gazzar paints The Charter, which commemorates Nasser's Charter, a new contract of socialist principles including the revolutionary redistribution of land rights to the peasants of Egypt. The legacy of surrealism in Gazzar's work can be seen in the influence of Giorgio de Chirico and Paul Delvaux on the composition of the piece, but also in the many layers of symbolism and meaning that complicate its message. The painting wins first prize at the exhibition of the tenth anniversary of the 1952 Free Officer's Revolution.

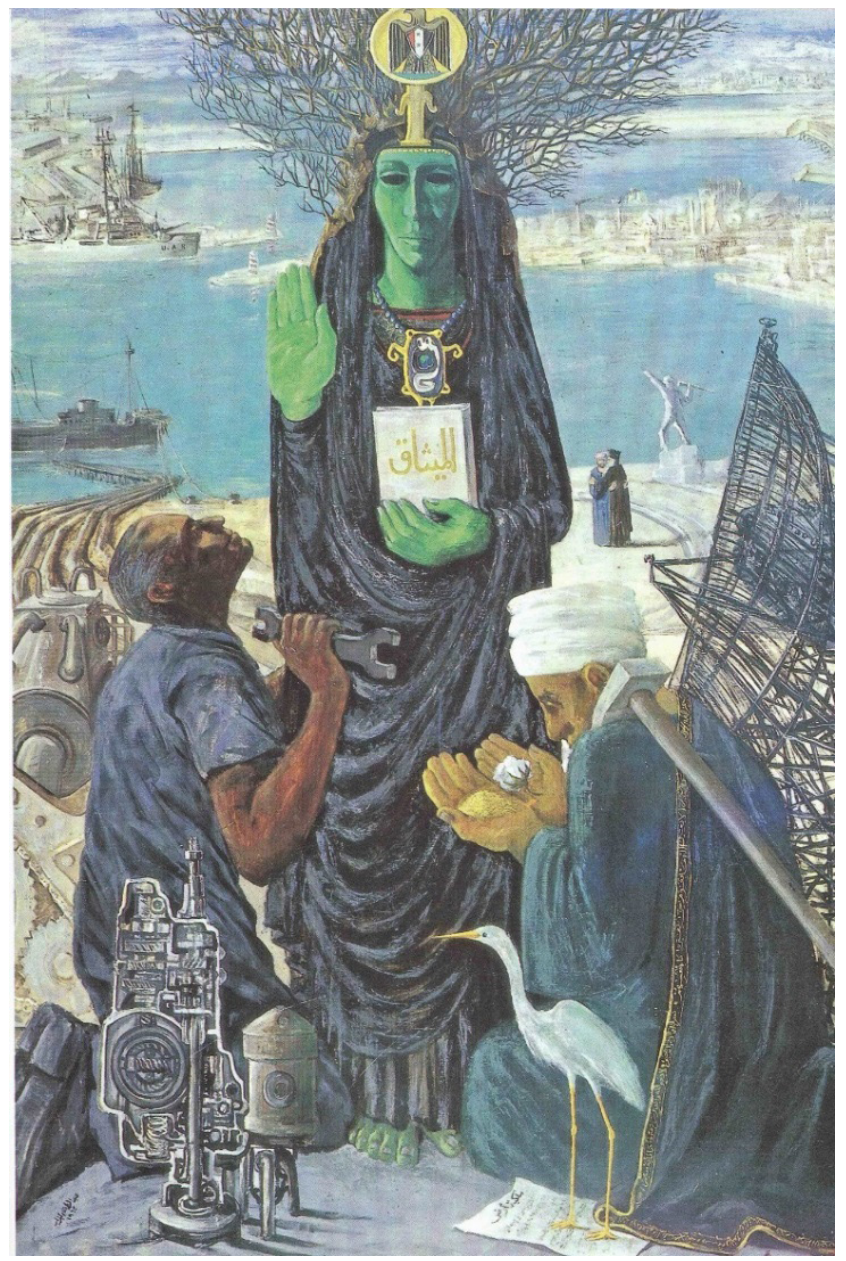

Figure 21: Abdel Hadi el-Gazzar, The Charter, 1962 (Museum of Modern Egyptian Art) 


\section{Legacy of Surrealism in Egypt}

The surrealist movement in Egypt fundamentally changed the way artists made, exhibited, and circulated art. The movement gave rise to art groups, such as the Contemporary Art Group and the Modern Art Group, which coalesced around certain shared artistic ideologies. Though, unlike their surrealist predecessors, these new groups endeavored to visually engage with a national Egyptian identity, at times in support of the new independent state, the surrealists also opened art to a more sustained dialogue with politics, and many artists saw their artwork as a vehicle for social change. Though the Sadat and Mubarak eras witnessed the fragmentation of the state art education and exhibition apparatus, the burgeoning political street art in Cairo after the January 25, 2011 Revolution represents a continuation of the integration of aesthetics and radical politics in Egypt. Thus, even though the surrealist movement did not take permanent root in its original incarnation, Egyptian artists have continued to employ the aesthetic techniques, ideological attitudes, and political networks introduced by this influential group.

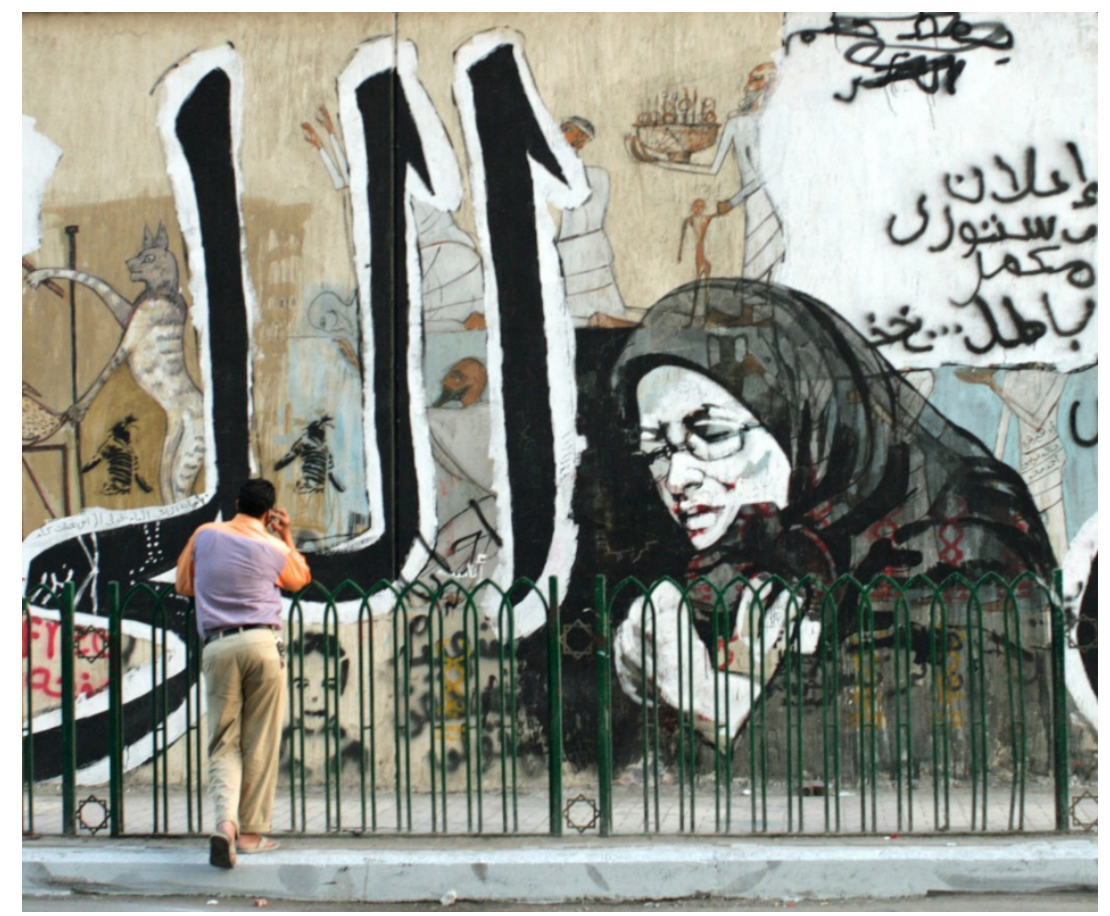

Figure 22: Street Art on Mohamed Mahmoud Street Cairo, Egypt, August 2012 


\section{Notes}

1. Many thanks to Patrick Kane, Fatenn Moustafa, Susanna Newbury, and Julia Elsky for their invaluable help on this piece.

2. The group's name was generally written in French as Art et Liberté and in Arabic as Gamā'at al-Fann wa al-Hurriyah. Other scholars (see LaCoss) have translated this as "Art and Liberty" in English. While the meaning of "freedom" and "liberty" are very similar, I believe that "freedom" better translates the original as it captures the active, rupturing nature of the group's ideals. (Eg. "freedom from" as opposed to "liberty to").

3. For a first-hand account of the hazing of new students at the École, see (Morrow 42-44).

4. Translation Alexandra Dika Seggerman, Julia Elsky and Donna Roberts

5. In her book The Arab Avant-Garde, Andrea Flores Khalil makes a convincing argument for the prescient post-structuralist theories apparent in this statement. She writes: “To make love with apparitions' is to create, in the 'true sense,' through the reflexive simulation between the objective and the subjective" (95).

\section{Works Cited}

Abū Ghāzì, Badr al-Dīn. Al-Maththāl Mukhtār. Cairo: al-Dār al-Qawmīyah lilTibā'ah wa-al-Nashr, 1964. Print.

Abū Ghāzì, Badr al-Dīn, and Gabriel Boctor. Mouktar, ou le reveil de l'Égypte. Cairo: Imprimiere de H. Urwand, 1949. Print.

Aflāțūn, Inzhī. Nahnnu al-nisā’ al-Mișrīyāt. Cairo: Maṭba'at al-Sa'ādah, 1950. Print.

Al-Alayle, Igbal. Vertu de l'Allemagne. [Anthologie par] Ikbal El Alaily. Cairo: Masses, 1945. Print.

Alexandrian, Sarane. Georges Henein. Paris: Seghers, 1981. Print.

Amin, Yusuf. Personal Interview. 17 Feb. 2012.

Carter, Howard. The Tomb of Tut-ankh-Amen. New York: Doran, 1923. Print.

Colla, Elliott. Conflicted Antiquities: Egyptology, Egyptomania, Egyptian Modernity. Durham: Duke UP, 2007. Print.

École Égyptienne des Beaux-Arts fondée par S.A. le prince Youssouf Kamal. Cairo: Imprimerie Paul Barbey, 1908. Print.

Effat, Leila. Personal Interview. 19 Dec. 2011.

Gershoni, Israel, and James P. Jankowski. Egypt, Islam, and the Arabs: The Search for Egyptian Nationhood, 1900-1930. New York: Oxford UP, 1987. Print.

Gharīb, Samīr. Al-Suryālīyah F̄̄ Mișr. Cairo: al-Hay’ah al-Mișrīyah al-'Āmmah lilKitāb, 1986. Print.

Henein, Georges. Déraisons d'être: Images de Kamel Telmisany. Paris: Corti, 1938. Print.

—. "Long Live Degenerate Art." London Bulletin 13 (1939).

and Ramses Younan. Notes sur un Acèse hysterique. Cairo: Part du Sable, 1948. Print. 
Khalil, Andrea Flores. The Arab Avant-Garde: Experiments in North African Art and Literature. Westport: Praeger, 2003. Print.

- "The Myth of the False: Ramses Younan's Post-Structuralism Avant La Lettre." The Arab Studies Journal 8/9.2/1 (2000): 97-110. Print.

LaCosse, Don. "Art and Liberty: Surrealism in Egypt." Communicating Vessels 21 (Fall-Winter 2009-2010): 28-33. Print.

Los Angeles County Museum of Art, and Art Institute of Chicago, eds. "Degenerate Art": The Fate of the Avant-Garde in Nazi Germany. Los Angeles: Los Angeles County Museum of Art, 1991. Print.

Morrow, W. C. Bohemian Paris of To-day. 3d ed. Philadelphia, London: Lippincott, 1900. Print.

Rosemont, Franklin, and Robin D. G Kelley, eds. Black, Brown, E Beige: Surrealist Writings from Africa and the Diaspora. 1st ed. Austin: U of Texas P, 2009. Print.

Rosemont, Penelope, ed. Surrealist Women: An International Anthology. Austin: U of Texas P, 1998. Print. The Surrealist Revolution Ser.

Sha'rāwī, Hudá. Harem Years: The Memoirs of an Egyptian Feminist (1879-1924). New York: Feminist P at the City U of New York, 1987. Print.

Telmissany, Kamel el-. "Hawla al-Fann al-Munhaṭ." Al-Risālah: Majallah Usbū‘īyah Lil-Ādāb Wa-al-'ulūm Wa-al-Funūn 7.321 (1939): 1700-03. Print.

“Al-Insāniyah wa al-Fann al-Hadīth." Al-Tatawwur 2 (1940): 45-48. Print.

- "L'Art en Egypte," Don Quichotte 17 (29 March 1940).
- Al-Soūq al-Soūda'. Studio Misr, 1945. YouTube. http://youtu.be/ 9zDNciFDbhc. 6 Aug. 2013. Web.

Telmissany, May. Personal Interview. 22 Feb. 2012.

Copyright (C) 2013 Alexandra Dika Seggerman 